\title{
Rethinking the Uses of Assessment in the Second Language Classroom
}

Repensar los usos de la evaluación en el aula para el aprendizaje de una segunda lengua

Repenser les usages de l'évaluation dans la salle de classe pour l'apprentissage d'une deuxième langue

Repensar os usos da avaliação na sala de aula para a aprendizagem de uma segunda língua

\begin{abstract}
One of the purposes of assessment is to provide results for different administrative uses. Using assessment exclusively focused on this aim does not improve teaching and learning. However, if assessment is used for learning, it can serve as a guide for analysis, discussion, and feedback to all those involved in the assessment process and represent an effective means to improve education. The main objective of this article is to discuss the uses of second language assessment as a learning tool. Based on research evidence, the article explains the concept of assessment for learning and describes four strategies that have proven effective in increasing student learning. As a concluding remark, the article emphasizes the need to change beliefs about the nature and role of assessment in the learning process.
\end{abstract}

\section{Keywords}

Assessment methods; goal setting; formative evaluation; self-assessment; feedback

\section{Transfer to practice}

The everyday practice of assessment in the classroom has many shortcomings. It is mainly focused on grades, rote learning, and record keeping. In contrast, assessment focused on learning by means of descriptive feedback, self and peer assessment has proven to be an effective approach to enhance teaching and learning. This paper offers four strategies that can help teachers usee assessment results to adapt their teaching practices to students' learning needs and thus help them become more critical and responsible of their own learning.

To cite this article / Para citar este artículo / Pour citer cet article / Para citar este artigo Muñoz-Restrepo, Ana (2017). Rethinking the Uses of Assessment in the Second Language Classroom. magis, Revista Internacional de Investigación en Educación, 9 (19), 115-132. doi: 10.11144/Javeriana.m9-19.ruas 


\section{Palabras clave}

Métodos de evaluación establecimiento de metas; evaluación formativa; autoevaluación; retroalimentación

\section{Resumen}

Uno de los propósitos de la evaluación es obtener resultados que sirvan para diferentes usos administrativos. Sin embargo, usar la evaluación únicamente con este objetivo no mejora la enseñanza ni el aprendizaje. Si la evaluación se utiliza para aprender, esta puede servir de guía para analizar, discutir y retroalimentar a todos los involucrados en el proceso de la evaluación y se convierte en un medio eficaz para mejorar la educación. El objetivo principal de este artículo es discutir los usos de la evaluación como herramienta para el aprendizaje de una segunda lengua. El artículo explica el concepto de la evaluación para el aprendizaje y describe cuatro estrategias que han demostrado ser eficaces para aumentar el aprendizaje de los estudiantes. Como conclusión, el artículo enfatiza la necesidad de cambiar las creencias respecto a la naturaleza y el papel de la evaluación en el proceso de aprendizaje.

\section{Transferencia a la práctica}

La práctica cotidiana de la evaluación en el aula tiene muchas deficiencias. Esta se centra principalmente en las calificaciones, el aprendizaje de memoria y el mantenimiento de registros. Por el contrario, la evaluación centrada en el aprendizaje - mediante la retroalimentación descriptiva, la autoevaluación y la evaluación entre pares- ha demostrado ser un enfoque eficaz para mejorar la enseñanza y el aprendizaje. Este artículo ofrece cuatro estrategias que podrían ayudar a los profesores a utilizar los resultados de la evaluación para adaptar sus prácticas de enseñanza a las necesidades de aprendizaje de sus estudiantes y, en este sentido, ayudarles a ser más críticos y responsables de su propio aprendizaje.

\section{Mots clés}

Méthodes d'évaluation; établir de défis; évaluations formatives; autoévaluation; feedback

\section{Résumé}

Un des propos de l'évaluation est celui d'obtenir les résultats qui marchent pour les différents usages administratifs. Cependant, utiliser l'évaluation uniquement avec cet objectif n'améliore l'enseignement ni l'apprentissage. Si l'évaluation est utilisée pour apprendre, celle-ci sert en tant que guide pour analyser, discuter et faire feedback avec tous les impliques dans le processus de l'évaluation, ainsi l'évaluation se transforme dans un moyen efficace pour améliorer l'éducation. L'objectif principal de cet article est de discuter les usages de l'évaluation en tant qu'outil pour l'apprentissage d'une deuxième langue. L'article explique le concept de l'évaluation pour l'apprentissage et fait une description de quatre stratégies qui ont montrées leur efficacité pour augmenter l'apprentissage des étudiants. En tant que conclusion, l'article signale le besoin de changer les croyances par rapport à la nature et le rôle de l'évaluation dans le processus d'apprentissage.

\section{Transfert à la pratique}

La pratique quotidienne de l'évaluation dans la salle de classe a beaucoup de déficiences. Notamment en ce qui concerne les qualifications, l'apprentissage de mémoire et le suivi de registres. Par contre, l'évaluation concentrée dans l'apprentissage - au moyen du feedback descriptif, l'autoévaluation et l'évaluation entre copains - cela a démontré être une perspective efficace pour améliorer l'enseignement et l'apprentissage. Cet article fournit quatre stratégies qui peuvent aider aux professeurs à utiliser les résultats de l'évaluation pour adapter leurs pratiques d'enseignement aux besoins d'apprentissage de leurs étudiants et, ainsi les aider à être plus critiques et responsables de leur propre apprentissage.

\section{Palavras-chave}

Métodos de avaliação; estabelecimento de metas; avaliação formativa; autoavaliação; retroalimentação

\section{Resumo}

Um dos propósitos da avaliação é obter resultados que sirvam para diferentes usos administrativos. No entanto, usar a avaliação unicamente com este objetivo não melhora o ensino nem a aprendizagem. Se a avaliação se utiliza para aprender, esta pode servir de guia para analisar, discutir e retroalimentar a todos os envolvidos no processo da avaliação e se torna um meio eficaz para melhorar a educação. O objetivo principal deste artigo é discutir os usos da avaliação como ferramenta para a aprendizagem de uma segunda língua. O artigo explica o conceito da avaliação para a aprendizagem e descreve quatro estratégias que têm demonstrado ser eficazes para aumentar a aprendizagem dos estudantes. Como conclusão, o artigo enfatiza a necessidade de mudar as crenças a respeito da natureza e do papel da avaliação no processo de aprendizagem.

\section{Transferência à prática}

A prática quotidiana da avaliação tem muitas deficiências. Esta se centra principalmente nas qualificações, na memorização e na manutenção de registros. Ao contrário, a avaliação centrada na aprendizagem - mediante a retroalimentação descritiva, a autoavaliação e a avaliação entre pares tem demonstrado ser um enfoque eficaz para melhorar o ensino e a aprendizagem. Este artigo oferece quatro estratégias que poderiam ajudar aos professores a utilizar os resultados da avaliação para adaptar suas práticas de ensino às necessidades de aprendizagem de seus estudantes e, neste sentido, ajudar-lhes a ser mais críticos e responsáveis por sua própria aprendizagem. 


\section{Introduction}

Assessment exclusively centered on achievement and summative in orientation is being increasingly questioned because of its limitations to capture real learning. It is widely known that summative assessment concentrates on measurement and report of student achievement mainly for administrative purposes (certifying competence, promoting from one level to another, informing stakeholders, etc.). An opposing orientation is the use of assessment for improving educational practices or formative assessment. Current research in education has provided evidence to support formative assessment or assessment for learning as a way to enrich student learning and improve teaching practices (Black, Harrison, Lee, Marshall \& Wiliam, 2003). Assessment for learning places emphasis mainly on the need to make the assessment criteria and learning objectives clear to students, on students' active participation in their own assessment, and on the role of feedback as a descriptive guide in the learning process (Black, Harrison, Lee, Marshall \& Wiliam, 2003).

Implementing assessment for learning requires a shift in the beliefs that administrators, policy makers, researchers, parents, and, especially, teachers have regarding the role of assessment in the classroom (Brown, 2004). Teachers, in particular, have the greatest responsibility in fostering assessment for learning. They are the ones who usually design and interpret assessment results. Therefore, they are responsible for changing their beliefs about the nature of assessment and its role in the learning process. Obviously, teachers alone cannot account for changes in assessment practices. It is also the duty of administrators to support teachers by providing them with professional development opportunities to help them make the desired changes. Such opportunities need to be understood in ways that offer teachers the flexibility to create assessment procedures and materials that can fit their specific teaching and learning contexts (Shohamy, Inbar-Lourie \& Poehner, 2008). Using assessment for learning can thus represent an alternative means to establish a more direct link between teaching, learning and assessment.

This article starts out by describing the concept of 'assessment for learning' in contrast to the concept of 'assessment of learning.' This is followed by a research-supported description of four strategies that can help integrate assessment in the teaching and learning process. The article concludes by acknowledging that the implementation of assessment for learning requires a shift in the beliefs that teachers and other stakeholders have regarding the role of assessment in education.

The methodology to gather the theoretical and practical viewpoints reported in this article followed different stages. First of all, based on my experience with several research studies in the area of assessment, I identified a topic, which I believe can have a tremendous impact on language education, i.e., assessment for learning. Having narrowed down the topic, I searched for relevant theory, in particular, exemplary research studies that could help me support the ideas presented. Second, I classified and grouped authors who drew similar conclusions about assessment for learning.

To develop the manuscript, I wrote a brief introduction where I described the general topic in order to provide an appropriate context for the article. Then, I created an organizational method to focus the sections by defining the concepts at the beginning of each section and adding different authors critical perspectives, sometimes showing awareness of opposing arguments, and including examples and practical recommendations to

\footnotetext{
Article description | Descripción del artículo | Description de l'article | Artigo descrição

This article is a reflection derived from several research studies conducted at the Language Center, Universidad EAFIT during 2004 and 2012 under the long term project: Design, validation, and effect of an English assessment system on teaching and learning. The author questions, first of all, the uses of assessment entirely focused on administrative purposes. Second, based on research evidence, she discusses the benefits of formative assessment and provides some assessment strategies that can help teachers establish a closer link between teaching, learning and assessment.
} 
support those arguments. For the conclusion, I briefly recaptured the ideas established in the introduction and elaborated on how teachers and students can embrace assessment for learning. I also concluded by providing some insight into the relationship between assessment for learning and a larger area of study such as teacher professional development.

\section{Assessment for learning}

Assessment for learning (Gipps, 1994; Stiggins, 2002, 2007) is the process by which teachers and learners use and interpret assessment results in order to decide "where they are in their learning, where they need to go, and how best to get there" (Assessment Reform Group, 2002). In other words, it involves any assessment designed to promote students' learning. In this sense, an assessment activity is considered to aid the learning process when it provides information that both teachers and students can use as feedback to adjust teaching and learning practices. Therefore, assessment for learning is formative; it helps teachers identify areas where further explanation or more practice is needed as well as which methodological changes can be implemented so that students are more successful in their learning (Burke, 2010). It also informs learners on how to make progress towards further learning. Central to such form of assessment is the student's own active participation in the learning process by developing metacognition, i.e. "the power to oversee and steer one's own learning so that one can become a more committed, responsible and effective learner" (Black \& Jones 2006, p. 8). In assessment for learning, students are highly involved through direct participation in assessing their own or their peers' work and through the descriptive and constructive feedback they receive from their teacher.

Some of the principles that guide assessment for learning are (Assessment Reform Group, 2002):

- It is embedded in a view of teaching and learning of which it is an essential part.

- It involves sharing learning goals with pupils.

- It aims to help students to know and to recognize the standards they are aiming for.

- It involves students in self-assessment.

- It provides feedback, which leads to students recognizing their next steps and how to take them.

- It is underpinned by the confidence that every student can improve.

- It involves both teacher and students reviewing and reflecting on assessment data.

The principles of assessment for learning can be contrasted with the characteristics of assessment of learning. Assessment of learning is focused on summative decisions. The purpose of summative assessment is to report student achievement at the end of a term, course or year, usually in the form of grades in order to determine knowledge and abilities developed over a specific period of time (Burke, 2010). This assessment usually has to meet an institution's administrative record keeping requirements for accountability purposes. In assessment of learning, the most important procedures for obtaining information regarding student performance are tests or quizzes. These techniques tell teachers how much students have learned and whether learning objectives have been 
met. In most cases, they are also used by administrators as an indicator of teachers' performance.

While results in assessment of learning methods are used to inform students, institutions, parents, and society in general about academic progress, assessment for learning is used to adapt teaching practices to learning needs (Burke, 2010). The main purpose of this assessment is to identify the learning and teaching difficulties rather than identify the amount of knowledge acquired. Common tasks used in assessment for learning include essays, portfolios, oral reports, projects, role-plays, demonstrations, debates, samples of student work, self and peer assessment, learning logs, individual or pair conferences, dialogue and response journals, interviews, etc. (Ataya, 2007). These tasks are regarded by many teachers a as a better way to determine how well students are learning (and how effective teaching is) than traditional forms of assessment like tests. This is due to the fact that these techniques are often more congruent with what is being taught in the classroom; they also emphasize the process of learning rather than the product, and they usually reflect different styles of teaching and learning much more effectively than standardized tests do (Miller, 1995).

The vital distinction between assessment for learning and assessment of learning is the purpose of the assessment itself or how the results are used (Chappuis \& Chappuis, 2008). In other words, the difference lies in the use of results as a learning tool to adjust teaching or learning practices (formative) or the use of results as a tool to measure and report the amount of knowledge acquired in a period of time (Dunn \& Mulvenon, 2009). Even though both types of assessment serve different purposes, they can work alongside to improve instruction. This would imply using the summative evidence provided by tests, for instance, to identify learning and teaching needs.

\section{Conditions for assessment for learning}

A paradigm shift in the uses of assessment has been brought forth by research evidence regarding the quality of traditional assessment practices (summative). In this sense, Paul Black, Christine Harrison, Clara Lee, Bethan Marshall \& Dylan Wiliam (2003, p. 11), contended that the everyday classroom assessment has many shortcomings:

- Teacher's tests encourage rote and superficial learning; even when teachers say they want to develop understanding.

- The assessment methods used are not discussed or shared among teachers, which means that they are not critically reviewed.

- There is a tendency to emphasize quantity of work over its quality.

- Grading is over-emphasized, while the giving of useful advice is deemphasized.

- The collection of grades to fill up record books is given greater priority than the analysis of student work to discern learning needs.

- Students are compared with one another; as a consequence, competition is promoted rather than personal improvement.

More conclusive in this change of paradigm has been the work done by Paul Black and Dylan Wiliam (1998). In an extensive survey of research literature, which included a revision of 250 articles and book chapters, these researchers concluded that the implementation of formative 
assessment practices can raise student achievement. In the schools reported in the studies, teachers used assessment techniques that deemphasized the value of scores and accountability and concentrated on the following formative strategies: 1) sharing learning objectives with students; 2) providing descriptive feedback; 3) engaging students in peer assessment; 4) involving students in self-assessment. In the section below, I will discuss each strategy using data from different research studies in order to provide more evidence of the positive effects of these assessment for learning practices.

\section{Sharing learning objectives with students}

According to Paul Black, Christine Harrison, Clara Lee, Bethan Marshall and Dylan Wiliam (2003), an essential part of assessment for learning is, first, the establishment of well-defined learning objectives and, second, sharing and discussing these objectives with the students. When teachers set clear learning objectives, students can better understand course expectations and thus concentrate their efforts on the accomplishment of those objectives (Turkay, 2014). Additionally, when students know what they are going to learn, why they are going to learn it (utility and benefit), and how they are going to learn it, it can be much easier for them to feel ownership of the learning objectives and be proactive (Elliot \& Fryer, 2008). This may lead to more motivation, effort, persistence, and creativity (Dewett, 2007; Zimmerman, 1990).

In other words, sharing and discussing objectives with students is important not only for establishing a direction for learning but also for assessing student performance and the effectiveness of teaching itself. If at the end of a lesson many students are unable to accomplish the proposed objectives, the teacher can use this information to revise her choice of class activities and teaching methodologies and how well they adapt to students' needs (proficiency level, meaningfulness of tasks, classroom environment, among others).

Sharing learning objectives with students initiates a reflection that allows students to establish their own goals and better examine their progress (Elliot \& Fryer, 2008). Multiple research studies show that students who perform better are those who understand both what the teacher intends to teach and how she intends to teach it (Jorba \& Sanmartí, 1994; Marzano, 2004). A study on the effect of oral assessment on teaching and learning conducted at a Colombian university (Muñoz \& Álvarez, 2010), revealed that students who were well aware the course and lesson objectives had higher score gains than students in a comparison group whose teachers only specified the type of activities to be conducted during the lesson. In another study reported by Drew C. Appleby (2002, p. 135), students expressed favourable opinions regarding making objectives explicit. One student said: "Teachers need to give better explanations of why students need to know the things they are learning in their classes and not just 'You need to know this.'" Another student commented: "When people are aware of the purpose of a task they are asked to perform, they usually perform it better."

Likewise, Edwin A. Locke, Karyll N. Shaw, Lise M. Saari and Gary P. Latham (1981) reported on an extensive review of the research on setting goals or objectives. They stated that the beneficial effect of "goal setting on task performance is one of the most robust and replicable findings in the psychological literature" (p. 145). In their revision, 90\% of the studies showed positive or partially positive effects of goal setting on performance. Locke and colleagues found that there are at least four 
mechanisms by which goals affect task performance: Namely, directing attention and action, mobilizing energy or effort, prolonging effort over time, and motivating the student to develop relevant strategies for goal attainment. Other studies reported by Robert J. Marzano, Debra J. Pickering and Jane E. Pollock (2001) have shown the effect of goal specificity on student performance. These studies concluded that objectives which are too specific in nature do not produce positive effects. Such objectives are called 'behavioural objectives' and are traditionally stated considering three characteristics (Mager, 1962, p. 21): 1) Performance (what a learner is expected to be able to do and the product or result of doing; 2) conditions (conditions under which the performance is to occur); and 3) criterion (the criterion of acceptable performance).

Example: Given simple reading materials such as letters, brochures and short newspaper articles describing events (conditions), the students will identify (performance verb) at least four specific pieces of information (criteria). Marzano and colleagues claimed that the objectives need to be general enough to provide students with some flexibility in performance. They considered that behavioural objectives are too specific and detailed to accommodate the subjective and constructivist nature of the learning process. The authors called for the need to share with students objectives that are more open and flexible so that they can be adapted to students' individual needs.

Example: By the end of the lesson, students will be able to identify specific information in different texts.

Learning objectives need to be stated in a language that is understandable for students. For example, at the beginning of the course teachers can provide students with a list of learning objectives written in a student-friendly language, then go over these objectives and, finally, invite students to discuss their meaning. This discussion can contribute to detect possible differences between the teacher intention and students' interpretation of the objectives. In other words, objectives need to be understood and agreed upon; simply assigning or imposing them will not generate the desired acceptance, commitment, and performance (Latham, 2003).

Another way to help students understand the learning objectives is rephrasing the meaning of difficult or unknown words to the students. For instance, if the objective is to make inferences about something that was read or spoken, the teacher might say: "Today, we are learning to infer. This means that we are learning to make reasonable guesses on the basis of clues" (Chappuis, 2005, p. 2). The teacher can also choose individual students to rephrase the objectives to the class in order to check for misunderstandings. Another way to find out whether students understood the objectives is to ask them questions such as 'Can you remind me of what we are trying to do?' or 'Why are we doing this?' while they are working on different tasks. This may be more effective than just asking 'Does everyone understand?' Furthermore, David Didau (2011) presents 51 creative ways to introduce learning objectives, for instance, using QR codes, rearranging scrambled objectives, leaving a key word out of the objective and asking students to find it, etc.

\section{Providing descriptive feedback}

Feedback can be defined as information provided by a teacher about a student's performance or understanding (Hattie \& Timperley, 2007). The power of feedback lies in the fact that it is descriptive and specific; that is, it informs students about what needs improvement, where they are with respect to learning objectives and also provides them with precise ideas on how to improve. Therefore, feedback of great quality is "highly specific, directly revealing or highly descriptive of what actually resulted, clear to the performer, and available or offered in terms of specific targets and standards" (Wiggins, 1998, p. 46). According to Carol R. Rodgers (2006), descriptive feedback is a conversation between teacher and student where the student reflects on and describes his experience as a learner, with the purpose of improving learning and deepening trust between teacher and student.

The most common form of feedback is to give students a grade, and in some cases, an additional comment. However, research has shown that giving grades or even giving grades and comments together does not improve learning (Butler, 1988; Lipnevich \& Smith, 2008). According to Paul Black, Christine Harrison, Clara Lee, Bethan Marshall and Dylan Wiliam (2003, 2004), giving grades alone does not tell students how to improve their work. The authors argued that focusing on grades or rewards leads students to compare themselves with others and to "focus on their image and status rather than encourage them to think about the work itself and how they can improve it" (p. 46). In other words, grades (letters or numerical scores) tend to direct students' attention to the self and away from the task, which can lead to negative effects on performance (Siero \& Van Oudenhoven, 1995; Szalma, Hancock, Dember \& Warm, 2006).

To date, a few studies on the effect of descriptive feedback on academic performance have been conducted. For instance, Avraham N. Kluger and Angelo DeNisi (1996) conducted a meta-analysis (607 effect sizes; 23,663 observations) on the effects of feedback and found that, on average, feedback increased achievement, but that in $40 \%$ of the studies, feedback actually worsened student performance. According to the researchers this was because feedback 
was ego-involving, that is, it focused on the person rather than on the quality of the work. In this type of feedback, scores, grades or other forms of reporting which encouraged comparison with others were used. The researchers reported that $60 \%$ of studies in which feedback had a positive impact on performance concentrated not only on what to improve, but also on how to improve. These findings are supported by Anastasiya Lipnevich \& Jeffrey K. Smith (2008) who investigated the effects of three types of feedback - no feedback, detailed feedback provided by the teacher, and detailed feedback provided by a computer- on writing performance. Overall, they found that detailed, descriptive feedback was most effective when given alone, unaccompanied by grades or praise.

Feedback focused on grades and comments together has also shown to be ineffective. This may be due to the fact that students concentrate exclusively on their scores or on their classmates' scores and hardly ever pay attention to the comments (Black \& Wiliam, 1998, 2002). Research by Ruth Butler (1988) showed that the most effective type feedback is focused on comments only. In her study, students received three types of feedback: grades, comments, and a combination of grades with comments. Results showed that the group given only comments had greater learning gains than the other groups. According to Emma Smith and Stephen Gorard (2005) the success of this type of feedback is due to the quality of the comments and not the absence of scores; the authors argued that there is no point in removing grades if teachers do not help students with valuable comments. For this reason, it is important that feedback comments be: 1) connected to the learning objectives or standards; 2) brief and clearly expressed (verbally or written) in language that students can understand; 3) addressed to each student's particular needs and not taken from pre-packaged comments. In addition, students need to be given enough time to analyse the comments. The value of well-crafted comments resides in their potential to transform a score that can lead to comparison and competition into a comment that can inform students of their particular strengths and weaknesses and thus further motivation and learning.

Feedback comments need to go beyond phrases like "Good work," "Excellent" or "You need to improve." These comments are not very helpful because they are too general, vague or, many times, based on teachers' subjective appraisal of a student's performance. Comments are more effective when they are descriptive and specific. For example, after a presentation by a student, the teacher can say: "Your presentation developed in an orderly and organized way. You included specific information that supported the topic. The content was powerfully focused and informative. Your performance related directly to the task specifications..." In this example, it is clear how the teacher describes each step of the development of the task and does not focus exclusively on the final step or result. Additionally, the teacher can provide guidance on what strategies the student can use to improve, avoiding judgements, mockery or comparisons with other students. Feedback comments can also guide students toward reflection and action, e.g. "go back to your notes and compare the different uses of 'future tense.' What differences can you see?"

Another aspect of feedback that needs to be clearly understood by students is the assessment criteria. A strategy that can be used to help students understand these criteria is to have them practice scoring anonymous work samples (oral or written) using a scoring tool (rubric or checklist). Students assess the sample(s) and then, as a whole class activity, discuss and defend their assessments, always using the language of the scoring instrument and trying to reach consensus on how thoroughly the task was completed. In addition, when teachers provide individual student feedback, they can highlight phrases (or descriptors of performance) in the scoring instrument that reflect the student's strengths and weaknesses. The job of the teacher is to help the student understand those descriptors by discussing the feedback with him. This interactive exercise helps the student understand the meaning of the descriptors and develop the essential skills required for peer and self-assessment. Engaging students in feedback discussion creates the opportunity for both teacher and students to actively construct an understanding of the descriptors and comments provided (Higgins, Hartley \& Skelton, 2001; Ivanic, Clark \& Rimmershaw, 2000). This means that the students not only receive information but also have the opportunity to participate in the feedback.

Another approach that has proved particularly powerful in clarifying the assessment criteria is to provide students with 'exemplars' of performance (Orsmond, Merry \& Reiling, 2002). Exemplars can be defined as "key examples chosen so as to be typical of designated levels of quality or competence. The exemplars are not standards themselves but are indicative of them ... they specify standards implicitly" (Royce Sadler, 1987, p. 200, cited in Handley \& Williams, 2009 , p. 3). For instance, for a writing learning objective such as 'narrate personal events in the past,' the teacher can offer students writing examples already annotated with feedback comments and scoring (This piece of writing is good and deserves a 4,5 score because...). The teacher can help the students interpret the comments and scoring in relation to the exemplars and then ask the students to use this knowledge when 
developing their own writing assignments. Exemplars are effective because they make explicit what is required from students and allow them to compare their work against the given sample. The use of exemplars may be mistakenly confused with the use of models; however, according to Karen Handley and Lindsay Williams (2009), models elicit imitation or copying while exemplars should be accompanied by a formative dialogue between teachers and students where students are led to drawing out "principles and insights about assessment criteria" (p. 4).

\section{Engaging students in peer assessment}

In peer assessment, students assess their classmates' work and provide feedback. This practice plays a crucial role in assessment for learning because it helps students critically examine their progress and understand their own learning better. Research has shown that if conducted appropriately, peer assessment can help students take more responsibility for their learning, foster collaboration skills, and improve autonomy (Reinders \& Lázaro, 2007).

A valuable characteristic of peer assessment, cited by Black, Harrison, Lee, Marshall, and Wiliam (2003), is that this form of assessment promotes positive peer pressure; that is, students can be more motivated to work when they know that their work is going to be checked by a peer. They might be more careful and organized with the material that they are going to be presenting. Another advantage of peer assessment is that it takes place in language that students themselves would naturally use. This helps "strengthen the student voice and improves communication between students and their teachers" (Black, Harrison, Lee, Marshall \& Wiliam, 2003, p. 50).

Research on peer assessment has shown that engaging students in collaborative learning and assessment has produced positive outcomes. For instance, a meta-analysis conducted by Nancy Falchikov and Judy Goldfinch (2000) showed a correlation of 0.69 between teacher and peer assessments, demonstrating that peer assessment can be reliable. Moreover, a recent quasi-experimental study by Lan Li and Fei Gao (2015) involving 130 student-teachers from a Midwestern university in the United States showed that, after the incorporation of a peer-assessment technique, low- and average-achieving students significantly improved their performance on a computerized lesson plan project whereas the impact was lesser on the high achieving students. In another study, Meichun Lydia Wen and Chin-Chung Tsai (2006) investigated university students' perceptions and attitudes towards peer assessment. The results showed that students had positive attitude toward the peer assessment activities and that they considered the peer assessment scores should be counted as a small part of the total course grade. Roy Ballantyne, Karen Hughes, and Aliisa Mylonas (2002) focused on the use of peer assessment in large classes. Their results indicated that the benefits received through peer assessment were greater than its shortcomings. Students reported that peer assessment encouraged them to compare and reflect on their own work. Students also expressed that peer assessment gave them the opportunity to develop metacognitive skills that they thought were useful for their future career. A negative finding about the peer assessment was the students' beliefs that their peers did not have the skills to assess each other; they thought that their peers might be either too lenient or very strict in scoring. Thu Thuy Vu and Gloria Dall'Alba (2007) also examined Australian university students' experience of peer assessment. The results showed that peer assessment had a positive effect on students' learning 
experiences. In this study, most students acknowledged learning from both the process and from their peers.

Some of the disadvantages of peer assessment cited in the literature are that students may not be qualified enough to be able to evaluate each other, that they may not take the assessment process seriously, or that they may be influenced by language level, friendship, and gender (Azarnoosh, 2013). Given its shortcomings, the literature offers some rules that can considerably decrease the problems of peer assessment and hence make it more effective (Majdoddin, 2010 p. 403):

a. Students should be presented with brief information on what they are supposed to do and what is expected of them;

b. Students need to be familiar with the purpose of the evaluation;

c. Students need to know what assessment criteria to follow;

d. Teachers need to make sure that students are following the criteria clearly and appropriately;

e. Students need to practice the process in stress-free environments;

f. Teachers should not expect peer assessment to be perfect at the first attempt.

In addition, teachers need to educate students in terms of what is expected from them in relation to the appropriateness of their comments and behaviors. For instance, students need to learn how to address each other respectfully, how to participate taking turns and how to listen to each other, among others. A frequently cited strategy that can be used to help students comment appropriately on each other's work is using "two stars and a wish." The student evaluator identifies two positive features of his peer's work (two stars) and one feature that he feels needs to be improved (the wish). This technique can be very successful because it is designed to elicit positive comments and, since these come from a peer, rather from than an authority figure, students are more likely to accept the feedback. A strategy that can be used for oral presentations is the "traffic light colours" (Black, Harrison, Lee, Marshall \& Wiliam, 2003). For example, if a student is uncertain about what is being communicated, red demonstrates that he needs his peer to stop and attempt the presentation again. Yellow means that the lesson can go forward, but with clearer explanation. Students are asked to justify their use of the colours. This technique can help students gain confidence in communicating with each other without being offensive.

An important aspect in scaffolding peer assessment practices is familiarizing students with the assessment criteria. This is particularly important for reaching consistent and reliable results between peers and between teacher and student ratings. To this end, a rubric may be used (See section below for an example of how to use the rubric). A rubric is a scoring tool that specifies the expectations for the successful accomplishment of a task. It describes "what constitutes acceptable or unacceptable levels of performance" for each component of the task (Stevens \& Levi, 2005, p. 3). Rubrics are extensively being used due to their effectiveness for grading. A study on the reliability of this instrument for peer assessment revealed that the rubric was used consistently by both students and the teacher along the duration of the study (three years) (Hafner \& Hafner, 2003). Likewise, Kwangsu Cho, Christian D. Schunn and Roy W. Wilson (2006) found high reliabilities between teacher and student ratings, implying that teachers should not be concerned by the implementation of peer assessments. 
Involving students in self-assessment

Self-assessment is a form of assessment that challenges students to think more objectively about their own performance and progress. James $\mathrm{H}$. McMillan and Jessica Hearn (2008, p. 40) contended that when "correctly implemented, student self-assessment can promote intrinsic motivation, internally controlled effort, a mastery goal orientation, and more meaningful learning." Therefore, students are encouraged to reflect on what they have learned, how well they have learned it, and how they can further their learning. This process often leads to students' feeling empowered to make decisions about their own learning needs and goals. Michael Harris (1997) stated that this reflection promotes awareness that allows students to view learning as a personal and individual path and not as an external or imposed set of obstacles to be overcome. Self-assessment can be used for different purposes: placement, diagnosis, feedback, assessment of attitudes and course grades. Different instruments can be implemented for each purpose: questionnaires, surveys, journals, portfolios, progress checklists, scoring grids, rubrics, can do statements, etc. (Henning, 1987).

One of the most important advantages of self-assessment is that it fosters student autonomy (Tholin, 2008). Self-assessment can thus be viewed by students as an experience of control over their learning process which, in turn, can lead to feelings of competence and autonomy (Deci, Vallerand, Pelletier \& Ryan, 1991; Tsai, Kunter, Lüdtke, Trautwein \& Ryan, 2008). Fostering autonomy through self-assessment can also help a student develop the ability to "think and act critically and independently, to self-manage study and learning, and realistically appraise strengths and weaknesses" (Crome, Farrar \& O'Connor, 2009, p. 112).

Despite the benefits of self-assessment, its lack of reliability is often cited in the literature, with self-assessment resulting in higher student grades than teacher assessment (Topping, 2003) or in more strict ratings by the students (Matsuno, 2009). However, many studies have shown that students can self-assess reliably and that there can be high correlations between student self-assessment and teacher assessments (Bachman \& Palmer, 1989; Muñoz \& Álvarez, 2007; Saito \& Fujita, 2004; Xiao \& Lucking, 2008). These results have been reported in terms of consistency across tasks, across items, and over short time periods (Ross, 2006). Positive results are possible if students are trained on how to self-assess and undergo different stages of support and guidance (Carter \& Nunan, 2001; Oscarson, 1989; Sung, Chang, Chang \& Yu, 2010). Training may involve the explanation of the purpose and benefits of self-assessment as well as familiarization with the assessment criteria, tools, and procedures. An activity to teach students how to self-assess is described in Ana P. Muñoz and Marta E. Álvarez (2007, pp. 8, 9). They reported on a study in which students were trained to self-assess in order to compare their scorings to those of their teachers. Students were also asked about their perception about the self-assessment activity. Results showed from moderate to high correlations and that students perceived the self-assessment practice as a beneficial activity. The self-assessment training was conducted in two stages, which are summarized as follows:

\section{Stage 1: Training session with students}

The teacher informed students about the purposes and benefit of self-assessment and then proceeded to conduct a training activity in which the teacher asked for a volunteer to perform an oral activity (picture description). This was followed by the teacher explaining to the whole class how to use the self-assessment instrument (rubric). Afterward, the teacher 
asked the volunteer to grade himself on three of the five aspects of the rubric, emphasizing that the scores were to be given based on the instrument descriptors. After that, the volunteer was asked to orally report the grades on the three aspects. Then, the teacher conducted a discussion session during which the volunteer was questioned about why a particular score was given, encouraging him to use the language (descriptors) of the scoring instrument. The discussion session also involved answering why certain scores were more appropriate than others.

\section{Stage 2: Self-assessment session}

In this stage, the teacher conducted an oral assessment activity where all students were required to self-assess on all the oral language aspects provided in the rubric. The teacher emphasized that scores needed to be based on the descriptors. After this, the teacher scored the students and wrote down detailed comments about their performance and collected the students' self-assessment reports. On the same day, or during the next class, the teacher provided feedback by giving students the ratings from the self and teacher assessments, plus comments on why certain scores were given.

The two-stage activity used in the study by Ana P. Muñoz and Marta E. Álvarez showed that it was possible for students to self-assess with more objectivity and that their scorings were very similar to those of their teachers'. Additionally, students perceived the self-assessment as a useful activity for raising awareness on their own learning (p. 12).

As previously stated, the success of self-assessment depends on students' training and guidance. Students need to clearly understand the assessment criteria and hold discussions sessions with the teacher where they reach consensus on scorings and talk about how well the activity worked. In addition to discussions with the teacher, students can share their self-assessments with peers who can give their own impressions, obviously using the assessment criteria. This kind of practice helps students to learn how to monitor themselves and be aware of their learning.

\section{Conclusion}

I presented four assessment practices that can help teachers and students rethink the uses of assessment in the classroom: 1) Sharing learning objectives with students; 2) providing descriptive feedback; 3) engaging students in peer assessment, and 4) engaging students in self-assessment. These assessment practices have proven essential in fostering learning whereas the effectiveness of summative assessments has been questioned due to its focus on the demonstration of knowledge and memory recall rather than the processes of learning.

In rethinking the uses of assessment, teachers can embrace assessment for learning as a tool to facilitate change. If teachers take the risk of implementing this practice, they will soon recognize its usefulness and benefits. Acceptance and recognition are already the first step for changing one's beliefs (Branden, 1999), which, in turn, can lead to changing one's assessment practices. Undoubtedly, changing assessment practices demands a change in teachers' beliefs since the way they teach is inevitably connected with their conceptions on education (Borg, 2003; Brown, 2004; Tillema, 1997). These practices place new demands on teacher knowledge and skills and are only effective if the teachers have certain beliefs about the nature and goals of assessment. Consequently, meaningful change in assessment practices will require that teachers reconsider the purposes of assessment, become aware, and clarify their own pedagogical stance. In so doing, reflection, risk-taking, and investing time and effort are crucial factors for the reconceptualization of new assessment practices. Teachers need, therefore, training opportunities, guidance, and support from their institutions to help them embrace the new approaches. This obviously requires that institutions be convinced of the utility and potential power of assessment for learning in enhancing education.

In assessment for learning, teachers need to integrate assessment into teaching and develop new strategies for collecting information and giving feedback. As well, the implementation of assessment for learning presupposes a shift in the role of students in the classroom and in their beliefs about assessment. Under this view, students are no longer passive recipients of knowledge, but active individuals in the learning process. Students are responsible for their own learning; they are expected to think critically, assess themselves, and work collaboratively with peers. To help students reconceptualise assessment, teachers can use information about students' knowledge, skills, or beliefs to identify any misconceptions or misunderstandings about assessment for learning. Teachers can use this knowledge as a starting point for persuading students of the benefits of this type of assessment and monitor changes in their perceptions as instruction proceeds. The role of the teacher is thus to help students in reconceptualising assessment practices by engaging them in such practices and raising awareness of their advantages and effectiveness.

Change in both teachers and students' conceptions of assessment can only happen relatively slow and through sustained programmes of professional development and individual support. Such programs need to offer opportunities for teachers to discuss 
with colleagues and reflect on their experience as it develops. This can help teachers have a better understanding of their experiences, purposes, and practices involved in assessment for learning.

\section{A final word}

This article serves as a starting point for institutions, teachers, and students to begin or enhance their assessment practices. Educational institutions and teachers have long assessed student learning using traditional tests. However, in order to reach out more effectively to students, assessment for learning acts as a reliable means to gain a more detailed understanding of the students' abilities, which can be used to inform instructional strategies, and hence improve overall performance. Thus this article provides different stakeholders, not only with theory, but also with practical ideas that can be applied to classrooms. It is also important for future research to build upon the concepts and studies discussed in the current article and collect data that support the benefits of assessment for learning in Colombia. Further, it is useful to consider how the ideas presented herein can contribute new knowledge to an understanding of language evaluation in the education domain.

\section{About the author}

Ana Muñoz-Restrepo is the coordinator of the Research Unit at the Language Center, Universidad EAFIT, Medellín. Her research areas of interest include second language assessment and language learning motivation.

\section{References}

Appleby, Drew C. (2002). Using Psychology Today, Articles to Increase the Perceived Relevance of the Introductory Course. In Richard A. Griggs (ed.). Handbook for Teaching Introductory Psychology with an Emphasis on Assessment, Volume III, 5-6. Mahwah, New Jersey: Erlbaum.

Assessment Reform Group (2002). Assessment for Learning: Ten Principles. Research-Based Principles to Guide Classroom Practice. Available at: http://assessmentreformgroup.files.wordpress.com/2012/01/10prin ciples_english.pdf

Ataya, Rosemarie L. (2007). Policy and Technical Considerations for Classroom Assessment. In Phyllis Jones, Judy F. Carr \& Rosemarie L. Ataya (eds.). A Pig Don't Get Fatter the More You Weigh it: Classroom Assessments That Work, 71-86. New York: Teachers College Press.

Azarnoosh, Maryam (2013). Peer Assessment in an EFL Context: Attitudes and Friendship Bias. Language Testing in Asia, 3 (11), 1-10. Available at: https://languagetestingasia.springeropen.com/arti cles/10.1186/2229-0443-3-11

Bachman, Lyle F. \& Palmer, Adrian S. (1989). The Construct Validation of Self-Ratings of Communicative Language Ability. Language Testing, 6, 14-25. Available at: https://www.researchgate.net/publica tion/249869979_The_construct_validation_of_self-ratings_of_com municative_language_ability

Ballantyne, Roy; Hughes, Karen \& Mylonas, Aliisa (2002). Developing Procedures for Implementing Peer Assessment in Large Classes Using an Action Research Process. Assessment \& Evaluation in Higher Education, 27 (5), 427-441. 
Black, Paul; Harrison, Christine; Lee, Clara; Marshall, Bethan \& Wiliam, Dylan (2003). Assessment for Learning: Putting it into Practice. Buckingham: Open University Press.

Black, Paul; Harrison, Christine; Lee, Clara; Marshall, Bethan \& Wiliam, Dylan (2004). Working inside the Black Box: Assessment for Learning in the Classroom. Phi Delta Kappan, 86 (1), 9-21.

Black, Paul \& Jones, Jane (2006). Formative Assessment and the Learning and Teaching of MFL: Sharing the Language Learning Road Map with the Learners. Language Learning Journal, 34 (1), 4-9.

Black, Paul J. \& Wiliam, Dylan (2003). The Development of Formative Assessment. In Brent Davies \& John West-Burnham (eds.). International Handbook of Educational Leadership and Management, 409-418. London, , United Kingdom: Pearson.

Black, Paul \& Wiliam, Dylan (1998). Assessment and Classroom Learning. Assessment in Education: Principles, Policy and Practice, 5 (1), 7-74.

Borg, Simon (2003). Teacher Cognition in Grammar Teaching: A Literature Review. Language Awareness, 12 (2), 96-108.

Branden, Nathaniel (1999). The Art of Living Consciously: The Power of Awareness to Transform Everyday Life. New York: Simon \& Schuster.

Brown, Gavin T. L. (2004). Teachers' Conceptions of Assessment: Implications for Policy and Professional Development. Assessment in Education: Principles, Policy \& Practice, 11 (3), 301-318.

Burke, Kay (2010). Balanced Assessment: From Formative to Summative. Bloomington, Indiana: Solution Tree Press.

Butler, Ruth (1988). Enhancing and Undermining Intrinsic Motivation: the Effects of Task Involving and Ego-Involving Evaluation on Interest and Involvement. British Journal of Educational Psychology, 58 (1), 1-14.

Carter, Ronald \& Nunan, David (2001). The Cambridge Guide to Teaching English to Speakers of Other Languages. Cambridge: Cambridge University Press.

Chappuis, Jan (2005). Helping Students Understand Assessment. Educational Leadership, 63 (3), 39-43. Available at: http://teachingss.pbworks. com/f/Helping\%2BStudents\%2BUnderstand\%2BAssessment.pdf

Chappuis, Stephen \& Chappuis, Jan (2008). The Best Value in Formative Assessment. Educational Leadership, 65 (4), 14-19.

Cho, Kwangsu; Schunn, Christian D. \& Wilson, Roy W. (2006). Validity and Reliability of Scaffolded Peer Assessment of Writing from Instructor and Student Perspectives. Journal of Educational Psycho/ogy, 98 (4), 891-901. Available at: https://pdfs.semanticscholar. org/26a6/92591bae818a72a33c5fd3bfc69e7735b257.pdf

Crome, Keith; Farrar, Ruth \& O'Connor, Patrick (2009). What is Autonomous Learning? Discourse: Learning and Teaching in Philosophical and Religious Studies, 9 (1), 111-126.

Deci, Edward L.; Vallerand, Robert J.; Pelletier, Luc G. \& Ryan, Richard M. (1991). Motivation in Education: The Self-Determination Perspective. Educational Psychologist, 26 (3\&4), 325-346. Available at: https:// pdfs.semanticscholar.org/6277/de5e8d8d8f39474eb754ef9bb8c 9c9b1c315.pdf

Dewett, Todd (2007). Linking Intrinsic Motivation, Risk Taking, and Employee Creativity in an R\&D Environment. R\&D Management, 37 (1), 197-208. Available at: http://www.optimizehire.com/wp-content/ uploads/2013/05/Dewett_IntrinsicCreativityRandD_2007.pdf

Didau, David (2011). Fifty-One Ways of Introducing Learning Objectives. Available at: http://www.slideshare.net/didau/51-ways-to-intro duce-learning-objectives-9929425 
Dunn, Karee E. \& Mulvenon, Sean W. (2009). A Critical Review of Research on Formative Assessment: The Limited Scientific Evidence of the Impact of Formative Assessment in Education. Practical Assessment, Research \& Evaluation, 14 (7), 1-11. Available at: http://pareonline. net/pdf/v14n7.pdf

Elliot, Andrew J. \& Fryer, James W. (2008). The Goal Construct in Psychology. In James Y. Shah \& Wendi L. Gardner (eds.). Handbook of Motivation Science, 235-250. New York: The Guilford Press.

Falchikov, Nancy \& Goldfinch, Judy (2000). Student Peer Assessment in Higher Education: A Meta-Analysis Comparing Peer and Teacher Marks. Review of Educational Research, 70 (3), 287-322. Available at: http://journals.sagepub.com/doi/pdf/10.3102/00346543070003287

Gipps, Caroline V. (1994). Beyond Testing: towards a Theory of Educational Assessment. London: Falmer Press.

Hafner, John C. \& Hafner, Patti M. (2003). Quantitative Analysis of the Rubric as an Assessment Tool: An Empirical Study of Student PeerGroup Rating. International Journal of Science Education, 25 (12), 1509-1528. Available at: https://sites.oxy.edu/hafner/publications/ hafner_hafner_2003.pdf

Handley, Karen \& Williams, Lindsay (2009). From Copying to Learning: Using Exemplars to Engage Students with Assessment Criteria and Feedback. Assessment \& Evaluation in Higher Education. Available at: http://www.uws.edu.au/_data/assets/pdf_file/0004/169834/an notated_exemplars_with_feedback1.pdf

Harris, Michael (1997). Self-Assessment of Language Learning in Formal Settings. ELT Journal, 51 (1), 12-20.

Hattie, John \& Timperley, Helen (2007). The Power of Feedback. Review of Educational Research, 77 (1), 81-112.

Henning, Grant (1987). A Guide to Language Testing: Development, Evaluation, Research. Rowley, Massachusetts: Newbury House.

Higgins, Richard; Hartley, Peter \& Skelton, Alan (2001). Getting the Message Across: The Problem of Communicating Assessment Feedback. Teaching in Higher Education, 6 (2), 269-274. Available at: http://nitro mart.co.uk/jem/docs/tt/getting\%20the\%20message\%20across.pdf

Ivanic, Roz; Clark, Ramy \& Rimmershaw, Rachel (2000). What am I supposed to Make of This? The Messages Conveyed to Students by Tutors' Written Comments. In Mary R. Lea \& Barry Stierer (eds.). Student Writing in Higher Education, 47-65. Buckingham, United Kingdom: Open University Press, New Contexts.

Jorba, Jaume \& Sanmartí, Neus (1994). Enseñar, aprender y evaluar: un proceso de regulación continua. Barcelona: Ministerio de Educación y Cultura. Available at: https://sede.educacion.gob.es/publiventa/vis taPrevia.action?cod $=41$ \&area $=\mathrm{E}$

Kluger, Avraham N. \& DeNisi, Angelo (1996). The Effects of Feedback Interventions on Performance: a Historical Review, a Meta-Analysis, and a Preliminary Feedback Intervention Theory. Psychological Bulletin, 119 (2), 254-284. Available at: http://citeseerx.ist.psu.edu/viewdoc/down load?doi=10.1.1.461.6812\&rep=rep1\&type $=$ pdf

Latham, Gary P. (2003). Goal Setting: A Five-Step Approach to Behavior Change. Organizational Dynamics, 32 (3), 309-318. Available at: http://bevhills.pbworks.com/f/Five-Step-Approach.pdf

Li, Lan \& Gao, Fei (2015). The Effect of Peer Assessment on Project Performance of Students at Different Learning Levels. Assessment and Evaluation in Higher Education, 41 (6), 885-900. doi:10.1080/02602 938.2015.1048185. 
Lipnevich, Anastasiya \& Smith, Jeffrey K. (2008). Response to Assessment Feedback: The Effects of Grades, Praise, and Source of Information. Educational Testing Service, ETS Research Report-08-30. Available at: https://www.ets.org/Media/Research/pdf/RR-08-30.pdf

Locke, Edwin A.; Shaw, Karyll N.; Saari, Lise M. \& Latham, Gary P. (1981). Goal Setting and Task Performance. Psychological Bulletin, 90 (1), 125-152.

Mager, Robert F. (1962). Preparing instructional objectives. Palo Alto, California: Fearon Publishers.

Majdoddin, Khadijeh (2010). Peer Assessment: An Alternative to Traditional Testing University of Tehran at Kish International Campus, Iran. The Modern Journal of Applied Linguistics, MJAL, 2 (5), 396-405. Available at: http://www.mjal.org/removedprofiles/2013/Peer\%20 assessment $\% 20 \mathrm{An} \% 20$ alternative $\% 20$ to\%20traditional\%20tes ting.pdf

Marzano, Robert J. (2004). Building Background Knowledge for Academic Achievement. Alexandria, Virginia: Association for Supervision and Curriculum Development, ASCD.

Marzano, Robert J.; Pickering, Debra J. \& Pollock, Jane E. (2001). Classroom Instruction that Works: Research-Based Strategies for Increasing Student Achievement. Alexandria, Virginia: Financial Times Prentice Hall.

Matsuno, Sumie (2009). Self-, Peer-, and Teacher- Assessments in Japanese University EFL Writing Classrooms. Language Testing, 29 (1), 75-100. Available at: http://citeseerx.ist.psu.edu/viewdoc/download?doi=10. 1.1.1030.1006\&rep $=$ rep1\&type $=$ pdf

McMillan, James H. \& Hearn, Jessica (2008). Student Self-Assessment: The Key to Stronger Student Motivation and Higher Achievement. Educational Horizons, 87 (1), 40-49.

Miller, Wilma H. (1995). Alternative Assessment Techniques for Reading \& Writing. San Francisco, California: Jossey-Bass.

Muñoz, Ana P. \& Álvarez, Marta E. (2007). Students' Objectivity and Perception of Self-Assessment in an EFL Classroom. The Journal of Asia TEFL, 4 (2), 1-25. Available at: http://www.eafit.edu.co/2014/idio mas/centro-idiomas/Documents/Student\%C2\%B4s\%200bjectivi ty\%20and\%20Perception\%20of\%20Self\%20Assessment\%20in\%20 an\%20EFL\%20Classroom.pdf

Muñoz, Ana P. \& Álvarez, Marta E. (2010). Washback of an Oral Assessment System in the EFL Classroom. Language Testing, 27 (1), 33-49. Available at: http://www.eafit.edu.co/2014/idiomas/centro-idiomas/Docu ments/Washback.pdf

Orsmond, Paul; Merry, Stephen \& Reiling, Kevin (2002). The Use of Exemplars and Student Derived Marking Criteria in Peer and SelfAssessment. Assessment \& Evaluation in Higher Education, 27 (4), 309-323. Available at: https://ccli-nsf.wikispaces.com/file/view/use_ of_exemplars_formative_feedback.pdf

Oscarson, Mats (1989). Self-assessment of Language Proficiency: Rationale and Applications. Language Testing, 6 (1), 1-13.

Reinders, Hayo \& Lázaro, Noemí (2007). Current Approaches to Assessment in Self-Access Language Learning. Teaching English as a Second or Foreign Language, TESL-EJ, 11 (3), 1-13. Available at: http://www. tesl-ej.org/ej43/a2.pdf

Rodgers, Carol R. (2006). Attending to Student Voice: The Impact of Descriptive Feedback on Learning and Teaching. Curriculum Inquiry, 36 (2), 209-237. 
Ross, John A. (2006). The Reliability, Validity, and Utility of Self-Assessment. Practical Assessment Research \& Evaluation, 11 (10). Available at: http://pareonline. net/getvn.asp? $v=11 \& n=10$

Sadler, D. Royce (1987). Specifying and Promulgating Achievement Standards. Oxford Review of Education, 13, 191-209.

Saito, Hidetoshi \& Fujita, Tomoko (2004). Characteristics and User Acceptance of Peer Rating in EFL Writing Classrooms. Language Teaching Research, 8, 31-54.

Shohamy, Elana; Inbar-Lourie, Ofra \& Poehner, Matthew E. (2008). Investigating Assessment Perceptions and Practices in the Advanced Foreign Language Classroom (Report No. 1108). University Park, Pennsylvania: Center for Advanced Language Proficiency Education and Research, CALPER. Available at: http://calper.la.psu.edu/sites/default/ files/pubfiles/CALPER_Assessment_Survey.pdf

Siero, Frans \& Oudenhoven, Jan Pieter van (1995). The Effects of Contingent Feedback on Perceived Control and Performance. European Journal of Psychology of Education, 10 (1), 13-24.

Smith, Emma \& Gorard, Stephen (2005). 'They Don't Give Us Our Marks': The Role of Formative Feedback in Student Progress. Assessment in Education: Principles, Policy \& Practice, 12 (1), 21-38. Available at: http://www.fp.ucalgary.ca/maclachlan/EDER_679.16_Winter_2008/ formative_assessment.pdf

Stevens, Dannelle D. \& Levi, Antonia J. (2005). Introduction to Rubrics: An Assessment Tool to Save Grading Time, Convey Effective Feedback, and Promote Student Learning. Sterling, Virginia: Stylus Publishing.

Stiggins, Richard J. (2002). Assessment Crisis: The Absence of Assessment for Learning. Phi Delta Kappan, 83 (10), 758-765. Available at: http:// www.electronicportfolios.org/afl/Stiggins-AssessmentCrisis.pdf

Stiggins, Richard J. (2007). Assessment through the Student's Eyes. Educational Leadership, 64 (8), 22-26.

Sung, Yao-Ting; Chang, Kuo-En; Chang, Tzyy-Hua \& Yu, Wen-Cheng (2010). How Many Heads are better than one? The Reliability and Validity of Teenagers' Self- and Peer Assessments. Journal of Adolescence, 33 (1), 135-145.

Szalma, James L.; Hancock, Peter A.; Dember, William N. \& Warm, Joel S. (2006). Training for Vigilance: The Effect of Knowledge of Results Format and Dispositional Optimism and Pessimism on Performance and Stress. British Journal of Psychology, 97, 115-135.

Tholin, Jörgen (2008). Learner Autonomy, Self-Directed Learning and Assessment: Lessons from Swedish Experience. Independence, 43, 9-12. Available at: http://www.diva-portal.org/smash/get/diva2:870506/ FULLTEXT01.pdf

Tillema, H. Harm (1997). Promoting Conceptual Change in Learning to Teach. Asia-Pacific Journal of Teacher Education, 25 (1), 7-16.

Topping, Keith (2003). Self and Peer Assessment in School and University: Reliability, Validity and Utility. In Mien Segers, Filip Dochy \& Eduardo Cascallar (eds.). Optimising New Modes of Assessment: In Search of Qualities and Standards, 55-87. Dordrecht, The Netherlands: Kluwer Academic Publishers.

Tsai, Yi-Miau; Kunter, Mareike; Lüdtke, Oliver; Trautwein, Ulrich \& Ryan, Richard M. (2008). What Makes Lessons Interesting? The Role of Situational and Individual Factors in Three School Subjects. Journal of Educational Psychology, 100 (2), 460-472. Available at: http://selfde terminationtheory.org/SDT/documents/2008_TsaiKunterLudtkeTra utweinRyanl_JEP.pdf 
Turkay, Selen (2014). Setting Goals: Who, Why, How? Manuscript. Retrieved from http://hilt.harvard.edu/files/hilt/files/settinggoals.pdf

Vu, Thu Thuy \& Dall'Alba, Gloria (2007). Students' Experience of Peer Assessment in a Professional Course. Assessment \& Evaluation in Higher Education, 32 (5), 541-556.

Wen, Meichun Lydia \& Tsai, Chin-Chung (2006). University Students' Opinions toward (Online) Peer Assessment. Higher Education, 51 (1), 27-44.

Wiggins, Grant (1998). Educative Assessment: Designing Assessments to Inform and Improve Student Performance. San Francisco, California: Jossey-Bass.

Xiao, Yun \& Lucking, Robert (2008). The Impact of Two Types of Peer Assessment on Students' Performance and Satisfaction within a Wiki Environment. The Internet and Higher Education, 11 (4), 186-193.

Zimmerman, Barry J. (1990). Self-Regulated Learning and Academic Achievement: An Overview. Educational Psychologist, 21, 3-17. 